\title{
MASASE MENGURANGI NYERI PERSALINAN PADA IBU BERSALIN
}

\author{
Nopita Yanti Sitorus ${ }^{1 *}$, Maimunah $\mathbf{R}^{2}$ \\ 1,2 Program Studi D-III Kebidanan STIKes Flora \\ *Korespondensi Email : nopistr27@gmail.com
}

\section{ABSTRACT THE EFFECT OF MASSAGE ON MOTHERS' PAIN DURING LABOR}

Introduction: Labor pain management can be implemented both non pharmacologically and pharmacologically. It can be done non pharmacologically without using drugs such as relaxation, massage, acupressure, acupuncture, hot or cold compresses and aromatherapy, while pharmacologically through the use of drugs. Non-pharmacological pain management is more secure, simpler, no bad side effect and reffering to mother caring than pharmacological pain management that potentially have adverse effect.

Purpose: To identify the effect of massage on mothers' pain during first stage labor.

Method: This is an analytical survey study with cross sectional method. It was taken place in Hadijah Maternity Clinic which is located in Medan. It was conducted from January to July 2021. The populations were 38 mothers who gave birth physiologically, that complained pain during first stage labor in Hadijah Maternity Clinic. The samples were part of the number and characteristics possessed by the population. There were 38 women chosen as the sample of the study that devided into 2 groups; control group and intervention group.

Results: The rate of pain intensity in intervention group before the massage was about 7,26 and after the massage was 4,74 with the value $p=0,000$. Whereas in control group, the rate of pain intensity before the massage was 7,00 and after the massage 6,16 with value $p=0,007$. So that the comparison after the massage which was carried out in the intervention and control groups obtained value $p=0,001$

Conclusion: There is a significant effect of the massage on the reduction of mothers' labor pain during first stage labor.

Suggestion clinics and hospitals to use the massage method as an intervention in reducing labor pain in the active phase of the first stage

Key words: Massage, Labor Pain, First Stage Labor

\section{ABSTRAK}

Pendahuluan : Manajemen nyeri persalinan dapat diterapkan secara non farmakologis dan farmakologis. Pendekatan secara non farmakologis tanpa penggunaan obat-obatan seperti relaksasi, masase, akupresur, akupunktur, kompres panas atau dingin dan aromaterapi, sedangkan secara farmakologis melalui penggunaan obat-obatan. Manajemen nyeri non farmakologis lebih aman, sederhana dan tidak menimbulkan efek merugikan serta mengacu kepada asuhan sayang ibu, dibandingkan dengan metode farmakologi yang berpotensi mempunyai efek yang merugikan

Tujuan : Mengidentifikasi pengaruh metode masase terhadap nyeri persalinan pada ibu inpartu kala I fase aktif. Metode : Jenis penelitian kuantitatif pendekatan quasy ekspreimen Lokasi penelitian di RB Hadijah yang terletak di Kota Medan. Penelitian dilakukan sejak bulan Januari sampai dengan bulan Juli 2021. Populasi penelitian adalah semua Ibu Bersalin Fisiologis yang mempunyai keluhan nyeri persalinan dengan partus pervaginam di RB Hadijah sebanyak 38 orang. Sampel adalah bagian dari jumlah dan karakteristik yang dimiliki oleh populasi. Sampel dalam penelitian ini sesuai dengan kriteria adalah sebanyak 38 orang dibagi menjadi 2 yaitu kelompok control dan kelompok intervensi

Hasil : Intensitas nyeri responden pada kelompok intervensi rata-rata skala nyeri sebelum dilakukan metode masase adalah 7,26 dan sesudah dilakukan metode masase adalah 4,74 diperoleh nilai $p=0,000$. Pada kelompok kontrol rata-rata skala nyeri sebelum dilakukan metode masase adalah 7,00 dan sesudah dilakukan metode masase pada kelompok kontrol 6,16 diperoleh nilai $p=0,007$. Sehingga perbandingan sesudah dilakukan metode masase pada kelompok intervensi dan kontrol diperoleh nilai $p=0,001$

Kesimpulan : ada pengaruh yang signifikan metode masase terhadap pengurangan nyeri persalinan pada ibu inpartu kala I fase aktif. 


\section{JKM (Jurnal Kebidanan Malahayati),Vol 7,No.4.Oktober 2021, ISSN (Print) 2476-8944 ISSN (Online) 2579-762X, Hal 726-730}

Saran klinik maupun rumah sakit supaya menggunakan metode masase sebagai salah satu intervensi dalam mengurangi nyeri persalinan kala I fase aktif

Kata Kunci : Metode masase, Nyeri Persalinan, Inpartu Kala I

\section{PENDAHULUAN}

Nyeri adalah proses alamiah dalam persalinan. Apabila tidak diatasi dengan baik akan menimbulkan masalah lain yaitu meningkatnya kecemasan karena kurangnya pengetahuan dan belum ada pengalaman pada ibu primigravida saat menghadapi persalinan sehingga produksi hormon adrenalin meningkat dan mengakibatkan vasokonstriksi yang menyebabkan aliran darah ibu ke janin menurun. Janin akan mengalami hipoksia sedangkan ibu akan mengalami persalinan lama dan dapat meningkatkan tekanan sistolik dan diastolik.

Manajemen nyeri persalinan dapat diterapkan secara non farmakologis dan farmakologis. Pendekatan secara non farmakologis tanpa penggunaan obat-obatan seperti relaksasi, masase, akupresur, akupunktur, kompres panas atau dingin dan aromaterapi, sedangkan secara farmakologis melalui penggunaan obat-obatan. Manajemen nyeri non farmakologis lebih aman, sederhana dan tidak menimbulkan efek merugikan serta mengacu kepada asuhan sayang ibu, dibandingkan dengan metode farmakologi yang berpotensi mempunyai efek yang merugikan.

Dalam persalinan, masase membantu ibu lebih rileks dan nyaman selama persalinan. Ibu yang yang di masase 20 menit setiap jam selama tahapan persalinan yang dilakukan oleh petugas kesehatan, keluarga pasien ataupun pasien itu sendiri akan lebih bebas dari rasa sakit, karena masase meransang tubuh melepaskan senyawa endorphin. Banyak bagian tubuh ibu bersalin yang dapat di masase, seperti kepala, leher, punggung dan tungkai. Saat memijat, pemijat harus memperhatikan respon ibu apakah tekanan yang diberikan sudah tepat (Lubis,2020).

Penelitian Rahmadani (2009) yang bertujuan untuk mengetahui pengaruh pijat punggung terhadap nyeri persalinan yang dilakukan pada 9 orangibu primipara kelompok intervensi dan 9 orang kelompok kontrol selama 30 menit dengan menggunakan desain quasy eksperimen diperoleh hasil bahwa sebelum dilakukan pijat, intensitas nyeri rata-rata 7,33 dan setelah dilakukan pijat punggung intensitas nyeri rata-rata 4,56. Hal ini menunjukkan bahwa pijat punggung dapat menurunkan intensitas nyeri persalinan pada ibu primipara kala I.
Penelitian Gadysa (2006) yang bertujuan untuk melihat pengaruh Massage Abdominal Lifting dengan menggunakan desain kualitatif pada 3 ibu inpartu diperoleh hasil bahwa 2 orang setuju dilakukan masase karena dapat mengurangi nyeri persalinan sedangkan 1 orang tidak nyaman dengan tindakan tersebut, sehingga disimpulkan bahwa Massage Abdominal Lifting dapat digunakan sebagai pertolongan pertama untuk mengurangi nyeri persalinan.

Penelitian Ratih (2010) yang bertujuan untuk mengetahui pengaruh metode masase yaitu Massage effleurage terhadap penurunan intensitas nyeri persalinan dengan menggunakan desain quasi eksperimen memberi hasil yang signifikan antara intensitas nyeri sebelum dan sesudah dilakukan intervensi pada kala I persalinan, sehingga disimpulkan bahwa masase ini efektif mengurangi intensitas nyeri persalinan.

Berdasarkan survei pendahuluan yang dilakukan oleh peneliti tanggal 22 Maret 2021 dengan metode wawancara pada 5 orang ibu bersalin, menyatakan bahwa mereka belum pernah mendengar tentang metode masase untuk mengurangi intensitas nyeri persalinan. Dari pengalaman 5 orang ibu bersalin tersebut, 3 orang mengatakan bahwa selama kontraksi ibu memperoleh tindakan pijat di punggung dan di pinggang yang dilakukan bidan dan pendamping persalinan, dan bidan menyuruh ibu untuk mencari posisi yang nyaman dan menarik nafas selama kontraksi, sedangkan 2 orang ibu hanya dianjurkan mengatur posisi yang nyaman dan menarik napas saat kontraksi. Hasil wawancara 9 orang bidan, 7 orang melakukan pijat pada punggung, pinggang ataupun sentuhan pada perut sedangkan 2 orang hanya menganjurkan pendamping persalinan untuk melakukan tindakan tersebut. Berdasarkan data di atas peneliti tertarik untuk melanjutkan penelitian sebelumnya tentang pengaruh metode masase terhadap nyeri persalinan pada ibu bersalin dengan teknik deep back massage.

\section{METODOLOGI PENELITIAN}

Jenis penelitian yang digunakan adalah survei analitik dengan rancangan penelitian cross sectional. Lokasi penelitian di RB Hadijah yang terletak di Kota Medan. Penelitian dilakukan sejak bulan Januari sampai dengan bulan Juli 2021. 
Populasi penelitian adalah semua Ibu Bersalin Fisiologis yang mempunyai keluhan nyeri persalinan dengan partus pervaginam di RB Hadijah sebanyak 38 orang. Sampel adalah bagian dari jumlah dan karakteristik yang dimiliki oleh populasi. Sampel dalam penelitian ini sesuai dengan kriteria adalah sebanyak 38 orang dibagi menjadi 2 yaitu kelompok control dan kelompok intervensi.Instrumen penelitian kuesioner

Analisis data kuantitatif dimaksudkan untuk mengolah dan mengorganisasikan data, serta menemukan hasil yang dapat dibaca dan dapat diintepretasikan, meliputi :Analisis Univariat yaitu dilakukan dengan statistik deskriptif untuk melihat frekuensi dan distribusi variabel bebas, variabel terikat. Tabel frekuensi digunakan untuk menggambarkan proporsi karakteristik subjek penelitian dengan melakukan pengkategorian variabel yang dianalisis, kemudian Analisis Bivariat yaitu Analisis yang dilakukan untuk mengetahui adanya hubungan antara variable independen dengan variable dependen dengan menggunakan $t$ test.

\section{HASIL PENELITIAN}

Tabel 1.

Distribusi Responden Berdasarkan karakteristik Data Demografi Ibu Inpartu pada Kelompok Intervensi dan Kelompok Kontrol

\begin{tabular}{|c|c|c|c|c|c|c|}
\hline \multirow{2}{*}{ Karakteristik Ibu Inpartu } & \multicolumn{2}{|c|}{ Jumlah } & \multicolumn{2}{|c|}{ Kelompok Intervensi } & \multicolumn{2}{|c|}{ Kelompok Kontrol } \\
\hline & $\mathbf{F}$ & $\%$ & $\mathbf{F}$ & $\%$ & $\mathbf{F}$ & $\%$ \\
\hline \multicolumn{7}{|l|}{ Usia } \\
\hline $18-23$ & 5 & $13,2 \%$ & & $15,8 \%$ & & $10,5 \%$ \\
\hline $24-29$ & 15 & $39,5 \%$ & & $42,1 \%$ & & $36,8 \%$ \\
\hline $30-35$ & 12 & $31,6 \%$ & & $31,6 \%$ & & $31,6 \%$ \\
\hline $36-40$ & 6 & $15,8 \%$ & & $10,5 \%$ & & $21,1 \%$ \\
\hline \multicolumn{7}{|l|}{ Paritas } \\
\hline 1 (Primipara) & 9 & $23,7 \%$ & & $26,3 \%$ & & $21,1 \%$ \\
\hline 2 (Scundipara) & 12 & $31,6 \%$ & & $31,6 \%$ & & $31,6 \%$ \\
\hline$>2$ (Multipara) & 17 & $44,7 \%$ & & $42,1 \%$ & & $47,4 \%$ \\
\hline \multicolumn{7}{|l|}{ Pendidikan } \\
\hline SD & 1 & $2,6 \%$ & & $5,3 \%$ & & - \\
\hline SMP & 3 & $7,9 \%$ & & $10,5 \%$ & & $5,3 \%$ \\
\hline SMA & 32 & $84,2 \%$ & & $73,7 \%$ & & $94,7 \%$ \\
\hline Perguruan Tinggi & 2 & $5,3 \%$ & & $10,5 \%$ & & - \\
\hline
\end{tabular}

Tabel 1 menunjukkan bahwa dari 19 orang kelompok intervensi sebagian besar responden berada pada rentang usia 24-29 tahun sebanyak 8 orang $(42,1 \%)$, paritas responden sebagian besar adalah multipara (>2 anak) sebanyak 8 orang $(42,1 \%)$, dan sebagian besar tingkat pendidikan responden adalah SMA sebanyak 14 orang
$(73,7 \%)$. Sedangkan pada 19 orang kelompok kontrol sebagian besar responden berada pada rentang usia 24-29 tahun juga sebanyak 7 orang $(36,8 \%)$, paritas responden sebagian besar adalah multipara (>2 anak) sebanyak 9 orang $(47,4 \%)$, dan sebagian besar tingkat pendidikan responden adalah SMA sebanyak 18 orang $(94,7 \%)$

Tabel 2.

Distribusi Responden Berdasarkan Intensitas Nyeri lbu Inpartu Sebelum dan Sesudah Dilakukan Intervensi Pada Kelompok Intervensi

\begin{tabular}{ccccc}
\hline Variabel & Mean & SD & Min-Max & $\mathbf{9 5 \%} \mathbf{C l}$ \\
\hline Intensitas Nyeri Sebelum dilakukan Intervensi & 7,26 & 1,195 & $5-9$ & $6,69-7,84$ \\
Intensitas Nyeri Sesudah dilakukan Intervensi & 4,74 & 1,147 & $3-7$ & $4,18-5,29$ \\
\hline
\end{tabular}

Tabel 2 menunjukkan hasil penelitian pada kelompok intervensi diperoleh intensitas nyeri sebelum dilakukan masase rata-rata 7,26 dengan standar deviasi 1,195, min-max 5-9 dan 95\% Cl nya adalah 6,69-7,84. Sesudah dilakukan masase ratarata 4,74 dengan standar deviasi 1,147, min-max 3-7 dan $95 \%$ Cl nya adalah $4,18-5,29$ 
Tabel 3.

Distribusi Responden Berdasarkan Intensitas Nyeri lbu Inpartu Sebelum dan Sesudah Dilakukan Intervensi Pada Kelompok Kontrol

\begin{tabular}{ccccc}
\hline Variabel & Mean & SD & Min-Max & $\mathbf{9 5 \% ~ C l}$ \\
\hline Intensitas Nyeri Sebelum dilakukan Intervensi & 7,00 & 0,816 & $6-8$ & $6,61-7,39$ \\
Intensitas Nyeri Sesudah dilakukan Intervensi & 6,16 & 1,259 & $4-8$ & $5,55-6,76$ \\
\hline
\end{tabular}

Tabel di atas menunjukkan Hasil penelitian pada kelompok kontrol diperoleh intensitas nyeri sebelum dilakukan masase rata-rata 7,00 dengan standar deviasi 0,816, min-max 6-8 dan 95\% Cl nya adalah 6,61-7,39. Sesudah dilakukan masase ratarata 6,16 dengan standar deviasi 1,259 min-max 4-8 dan $95 \%$ Cl nya adalah 5,55-6,76

Tabel 4.

Perbandingan Intensitas Nyeri Sesudah di Lakukan Masase Pada Kelompok Intervensi dan Kelompok Kontrol

\begin{tabular}{lccccc}
\hline \multicolumn{1}{c}{ Variabel } & Mean & SD & SE & P value & $\mathbf{n}$ \\
\hline Kelompok Intervensi & 4,74 & 1,147 & 0,263 & \multirow{2}{*}{0,001} & \multirow{2}{*}{38} \\
Kelompok Kontrol & 6,16 & 1,259 & 0,289 & & \\
\hline
\end{tabular}

Tabel di atas Hasil penelitian intensitas nyeri pada kelompok intervensi dan kelompok kontrol sesudah dilakukan masase diperoleh rata-rata skala nyeri 4,74 dengan standar deviasi 1,147 dan standar error 0,263. Rata-rata skala nyeri sesudah dilakukan metode masase pada kelompok kontrol 6,16 dengan standar deviasi 1,259 dan standar error 0,289 . Hasil uji statistik didapatkan nilai $p$ adalah 0,001 maka dapat disimpulkan bahwa ada perbedaan signifikan dari skala nyeri sesudah dilakukan metode masase pada kelompok intervensi dan kontrol

\section{PEMBAHASAN}

Dari hasil uji statistik t-dependent dan tindependent diperoleh kesimpulan bahwa ada pengaruh yang signifikan pada pengurangan nyeri persalinan kala I fase aktif sebelum dan sesudah dilakukan metode masase pada kelompok intervensi dan kelompok kontrol.

Sebuah penelitian menyebutkan, ibu yang di masase 20 menit setiap jam selama tahapan persalinan akan lebih bebas dari rasa sakit. Hal ini dikarenakan masase meransang tubuh melepaskan senyawa endorphin yang dapat menghilangkan sakit secara alamiah sehingga lebih nyaman (Sukmaningtyas,2016). Dianjurkan selama persalinan agar masase dilakukan terus-menerus, karena rasa nyeri cenderung akan meningkat jika masase dihentikan. Hal tersebut terjadi karena sistem saraf menjadi terbiasa terhadap stimulus dan organ-organ indra berhenti merespons nyeri tersebut (Fitri,2018).
Dari uraian di atas, maka hipotesa penelitian dapat dijawab bahwa metode masase berpengaruh terhadap pengurangan intensitas nyeri pada persalinan kala I fase aktif dan ada perbedaan pengurangan intensitas nyeri yang dirasakan sebelum dan sesudah dilakukan masase pada kelompok intervensi dan kontrol serta perbedaan signifikan sesudah dilakukan masase pada kedua kelompok tersebut.

Hasil penelitian ini menggambarkan bahwa metode masase sebagai salah satu metode pengendalian nyeri secara non-farmakologi yang berpengaruh terhadap pengurangan nyeri persalinan kala I fase aktif. Oleh sebab itu, metode masase dapat digunakan sebagai intervensi dalam asuhan kebidanan pada ibu inpartu kala I fase aktif yang mempunyai keluhan nyeri dalam persalinan tanpa efek samping pada ibu dan bayi.

\section{SIMPULAN}

Karakteristik demografi responden diperoleh bahwa dari 19 orang kelompok intervensi sebagian besar responden berada pada rentang usia 24-29 tahun sebanyak 8 orang $(42,1 \%)$. Berdasarkan paritas responden sebagian besar adalah multipara (>2 anak) sebanyak 8 orang $(42,1 \%)$, dan sebagian besar tingkat pendidikan responden adalah SMA sebanyak 14 orang $(73,7 \%)$. Sedangkan pada 19 orang kelompok kontrol sebagian besar responden berada pada rentang usia 24-29 tahun juga sebanyak 7 orang $(36,8 \%)$. Berdasarkan paritas responden sebagian besar adalah multipara $(>2$ anak) sebanyak 9 orang $(47,4 \%)$, dan sebagian 
besar tingkat pendidikan responden adalah SMA sebanyak 18 orang $(94,7 \%)$.

Intensitas nyeri responden pada kelompok intervensi rata-rata skala nyeri sebelum dilakukan metode masase adalah 7,26 dan sesudah dilakukan metode masase adalah 4,74 diperoleh nilai $p=0,000$. Pada kelompok kontrol rata-rata skala nyeri sebelum dilakukan metode masase adalah 7,00 dan sesudah dilakukan metode masase pada kelompok kontrol 6,16 diperoleh nilai $p=0,007$. Sehingga perbandingan sesudah dilakukan metode masase pada kelompok intervensi dan kontrol diperoleh nilai $p=0,001$.

Hasil uji statistik t-dependen kelompok intervensi nilai $p=0,000$ dan kelompok kontrol nilai $p=0,007$, sedangkan $t$-independen didapatkan nilai $p$ adalah 0,001, maka dapat disimpulkan bahwa ada pengaruh yang signifikan metode masase terhadap pengurangan nyeri persalinan pada ibu inpartu kala I fase aktif.

\section{SARAN}

Bagi Praktek Kebidanan ; Untuk bidan di klinik maupun rumah sakit supaya menggunakan metode masase sebagai salah satu intervensi dalam mengurangi nyeri persalinan kala I fase aktif. Bagi Pendidikan Kebidanan; Hasil penelitian ini perlu di integrasikan dalam mata kuliah asuhan kebidanan ibu bersalin (ASKEB II) sebagai pengembangan ilmu. Bagi Penelitian Kebidanan ; Penelitian ini dapat dilanjutkan dengan batasan paritas dan pembukaan serviks yaitu sama-sama primigravida dengan pembukaan yang sama. Bagi Responden ; Untuk dapat melakukan masase ataupun pendamping persalinan yang melakukannya sebagai salah satu intervensi untuk mengurangi intensitas nyeri ibu selama proses persalinan kala I fase aktif.

\section{DAFTAR PUSTAKA}

Arifin, L. (2008). Teknik Akupresur pada Persalinan. Diambil 22 September 2010, dari http://keperawatan maternitas.blogspot.com
Bare, B. G., dan Smeltzer, S. C. (2001). Buku Ajar Keperawatan Medikal Bedah Brunner dan Suddarth. Jakarta : EGC

Depkes RI. (2010). Visi Misi Indonesia Sehat. Diambil 22 September 2010, dari http://www.depkes.go.id

Fraser, D. M., dan Cooper, M. A. (2009). Buku Ajar Bidan Myles. Ed-14. Jakarta : EGC

Fitri, L., Noviawanti, R., \& Sasrawita, S. (2018). Efektivitas Stimulasi Kutan Slow Stroke Back Massage terhadap Penurunan Intensitas Nyeri Bersalin. Jurnal Endurance: Kajian IImiah Problema Kesehatan, 3(2), 232-237.

Gadysa, G. (2009). Persepsi Ibu Tentang Metode Masase. Diambil 27 September 2010, dari http://luluvikar.wordpress.com

Leveno, K., J. (2009). Obstetri Williams. Ed-21. Jakarta : EGC

Lubis, D. R., Maryuni, M., \& Anggraeni, L. (2020). Efektivitas Massage Punggung Dalam Mengurangi Nyeri Persalinan Kala I Fase Aktif Pada Primigravida \& Multigravida. Jurnal IImiah Bidan, 5(1), 11-21.

Rahmadani, F. (2009). Pengaruh Pijat Punggung Terhadap Penurunan Intensitas Nyeri Persalinan Kala I Fase Aktif Pada Ibu Primipara. Medan : tidak dipublikasikan

Ratih, R. H. (2010). Pengaruh Metode Masase Terhadap Pengurangan Intensitas Nyeri Pada Persalinan Kala I. Medan : tidak dipublikasikan

Sukmaningtyas, W., \& Windiarti, P. A. (2016). Efektivitas endorphine massage terhadap tingkat kecemasan ibu bersalin primipara. Bidan Prada: Jurnal Publikasi Kebidanan Akbid YLPP Purwokerto, 7(1).

Tim Penyusun Program D-IV USU. (2010). Panduan Penulisan Karya Tulis IImiah. Medan : tidak dipublikasikan

Walsh, L. V. (2007). Buku Ajar Kebidanan Komunitas. Jakarta : EGC 